\title{
QUESTION PATTERNS AND CONVERSATION IMPLICATURE ON TRADITIONAL MARKET IN LAMPUNG-INDONESIA
}

\author{
Bambang Prastio, Istiqomah Nurzafira, A. Syukur Ghazali, and Yuni Pratiwi \\ State University of Malang \\ email: bambangb409@gmail
}

\begin{abstract}
The purpose of this study was to describe the patterns and functions of questions expressed in conversational implicature found in market transactions. A descriptive qualitative method was used in this research. And conversation analysis was applied to determine question patterns, while conversational implicature was to examine question functions. The research data was collected in the form of recorded and transcripted conversations along with the corresponding situations or contexts. The data of this research was primarily obtained from both sellers and buyers in Way Halim Market, Lampung, Indonesia, and it was gathered by listening and taking notes. This study showed that there were six types of question patterns found in such transactions that contained conversational implicature, namely (1) yes/no question for asking, (2) tag question for rejecting and ordering (3) declarative question for ordering, (4) alternative question for asking, (5) wh-question for asking and sugesting, and (6) rhetorical question for rejecting. The results also indicated that the sellers used persuasive implied questions more often than the buyers. These questions functioned to persuade buyers politely to make purchase.
\end{abstract}

Keywords: question patterns, implicature, market transactions

\section{POLA PERTANYAAN DAN IMPLIKATUR PERCAKAPAN DI PASAR TRADISIONAL LAMPUNG-INDONESIA}

\begin{abstract}
Abstrak
Tujuan penelitian ini untuk mendeskripsikan pola dan fungsi tuturan pertanyaan yang disampaikan dalam implikatur percakapan ketika melakukan transaksi jual beli. Pendekatan penelitian ini adalah kualitatif deskriptif. Adapun jenis penelitian dalam menganalisis data menggunakan analisis percakapan untuk menentukan pola pertanyaan dan implikatur percakapan untuk menentukan fungsi tuturan pertanyaan. Data penelitian berupa tuturan percakapan hasil rekaman yang telah ditranskrip serta situasi atau konteks percakapan yang melatarbelakangi peristiwa tersebut. Sumber data penelitian ini diperoleh dari para pedagang dan pembeli di Pasar Way Halim, Provinsi Lampung, Indonesia. Pengumpulan data menggunakan metode simak dan metode catat. Hasil penelitian ini ditemukan enam bentuk pola pertanyaan dalam transaksi jual beli yang mengandung implikatur percakapan, yaitu (1) yes/no question fungsi meminta, (2) tag question fungsi menolak dan menyuruh (3) declarative question fungsi menyuruh, (4) alternative question fungsi meminta, (5) wh-question fungsi meminta dan menyarankan, dan (6) rhetorical question fungsi menolak. Dari data yang
\end{abstract}


ditemukan, penjual lebih sering menggunakan tuturan pertanyaan bersifat persuasif dengan makna yang disampaikan secara tidak langsung kepada pembeli. Fungsi penggunaan tuturan persuasif tersebut yakni penjual terlihat memiliki kesantunan sehingga mempengaruhi pembeli dengan harapan akan terjadi transaksi jual beli.

Kata kunci: pola pertanyaan, implikatur, transaksi jual-beli

\section{INTRODUCTION}

It is important to comprehend a variety of question patterns since it helps interlocutors to grasp the meaning of a question given. Question patterns are typical characteristics of expressed questions. As stated by Levinson (2010), question patterns are typical characteristics of questions expressed in interaction by which speakers and interlocutors are building social relation. Sakhiyya (2017) said that questions serve as a potential means to build an identity in social interaction in order to help speakers communicate with others. Questions become an important aspect to get information, so they are often chosen by speakers for achieving that purpose. Prastio et al., (2019); Prastio et al., (2020) considered questions as a crusial aspect of communication to gain information from interlocutors. Besides, the questions are the most essential aspect of language events in daily life, it is due to most of the communication is used to ask and answer questions (Hafrianto \& Mulyadi, 2018). In this regard, the research on questions, especially the pattern of questions is very necessary to be undertaken.

When a speaker asks a question, he assumes the interlocutor already knows the meaning of the question. According to, Gawne (2016) an interlocutor will do as a speaker expects. In fact, in everyday life, people normally still find it hard to understand implied utterances made by others. Vallejo (2017); George \& Mamidi(2020) said that those utterances are most likely to be conversational implicature due to the implicit meaning. Therefore, it is necessary to understand conversational implicature to reveal the real meaning of implied utterances. Grice (1975); Bezhanishvili et al., (2011) said conversational implicature is very useful for interpreting the intention of an interlocutor. In the other words, implicature helps to avoid misinterpretation that may occur to an interlocutor's intention and purpose. This is in line with what was stated by Salmon (2011); Ratu et al., (2018); Shardimgaliev (2019) conversational implicaturehelpsreveal thetruemeaning of an implied utterance without being exposed to misinterpretation.

Besides the literal meaning, the context of a conversation is also much needed in order to understand conversational implicature. The context links closely to the following aspects: situation, condition, and local culture. Bezuidenhout \& Morris (2004); Lee (2019) stated that to understand a context of conversation, it is necessary to take a look at a text beyond it. This text actually relates to the general knowledge of the world, including the culture, society, situation, and condition of a conversation. Consequently, the real meaning of an implied utterance will reveal thanks to these aspects. 
Traditional markets undoubtedly show human characteristics, enabling sellers and buyers to build a family relationship. The existence of traditional markets firmly adheres to social relation, norms, and trust as seen in the bargaining. A distinctive feature of traditional markets is that conversational implicature frequently happen in market transactions and bargains, which helps extend the network and loyalty among visitors. Market transactions are basically a kind of social interaction that involves language and culture. Aliyah et al., (2017); Paul et al., (2018) said that traditional markets are not only a place of trade but also a space for interaction and culture. And languange is one of the elements of a culture. In this regard, Koentjaraningrat (2016) mentioned language, knowledge systems, social organizations, living equipment, livelihoods, religion, and art as cultural elements. In the other words, when sellers and buyers make transactions, they use both language as a means of communication and culture a tool for bargains.

The relevant researches of the last decade are as follows. First, Sakhiyya (2013) came with the title Question Formation of Indonesian as a Second Language. The study looked at the differences in the patterns of English and Indonesian questions by Indonesian language learners for Foreign Speakers. The results indicated that there are four question patterns in Indonesian that are produced by second language learners. Second, Hamdani\&Barnes(2018)wrote under the topic of question patterns in Indonesian in daily life. This study focused on examining question patterns containing additional particles and their functions. The research findings showed yes/no question patterns, ya particle, and -kan particle. Third, Prastio et al., (2019) opted to conduct a research on Conversation Implicature in Interrogative Utterance of The Discourse of E-Commerce Business Advertisement. Basically, this research aimed to examine questions that contained conversational implicature in e-commerce advertising. The results showed that interrogative utterance has five functions, namely ordering, banning, rejecting, suggesting, and asking. This study appeared to be different from the previous one because of combining two scopes (question patterns and implicature) and taking place in a different area for data collection.

As a semi-modern market, Way Halim Market is one of the biggest traditional markets located in Lampung. This market is situated in a strategic place, considering the fact that it lies in the heart of Bandar Lampung City, which is quite reachable by any people of around Lampung. A wide variety of languages from diversified tribes is spoken in this market as a means of interaction, allowing for complex utterances in term of question patterns and their functions. In addition, The speech act of question has not yet been found by the researcher, particularly the pattern of questions and theimplications of conversations in the market.

This researcher focuses on the question patterns and functions of the questions during the process interaction of buying and selling occurs between the seller and the buyer in the Market of Way at Halim-Lampung. Based on this matter, this research has to be carried 
out due to a number of reasons: (1) finding the question patterns will help determine the typical characteristics of implied questions, (2) understanding the conversational implicature will lead to the functions of implied utterances, (3) it remains difficult to find research that combines both conversational analysis and conversation implicature. Thus, combining these two is expected to pave the way for solutions, patterns, and functions of questions as to help people reveal the true meaning of an implied utterance.

\section{METHODS}

A descriptive qualitative method was used this research. A conversation analysis approach was applied to determine question patterns. According to Channon et al., (2018) conversational analysis centers around repetitive and systematic patterns of conversation that are used informally in a particular community. While pragmatics, especially conversational implicature, was used to examine question functions for data analysis. Pragmatic focuses on research based on speech function (Ratu et al., 2018). The data was collected from both sellers and buyers at Way Halim Market, Lampung Province, Indonesia. The data of this research was gathered in the form of recorded and transcripted conversations along with the corresponding situations or contexts. The data was collected by listening and taking notes.
The instrument of this research was a researcher who acted as a human instrument equipped with a theoretical and methodological understanding. Additionally, there were also complementary instruments used for collecting and analyzing data. Apart from it, the validity check of the data in this study followed three techniques: constant careful observation, triangulation (prior to the data analysis), and peer and supervisor discussions. In this regard, the triangulations of this research covered source triangulation, methodological triangulation, and theory triangulation; and the discussions were carried out with selected colleagues considered to have knowledge about conversational implicature and lecturers working in the field of functional linguistics.

\section{RESULT AND DISCUSSION Results}

This study found that the forms of question patterns in buying and selling transactions that contained conversational implicature had their respective functions. There were question patterns and their functions, i.e. (1) yes/no question for asking, (2) tag question for refusing and ordering, (3) declarative question for ordering (4) alternative question for requesting, (5) $\mathrm{WH}$-question for asking and sugesting, and (6) rhetorical question for refusing. The findings can be seen in Figure 1. 


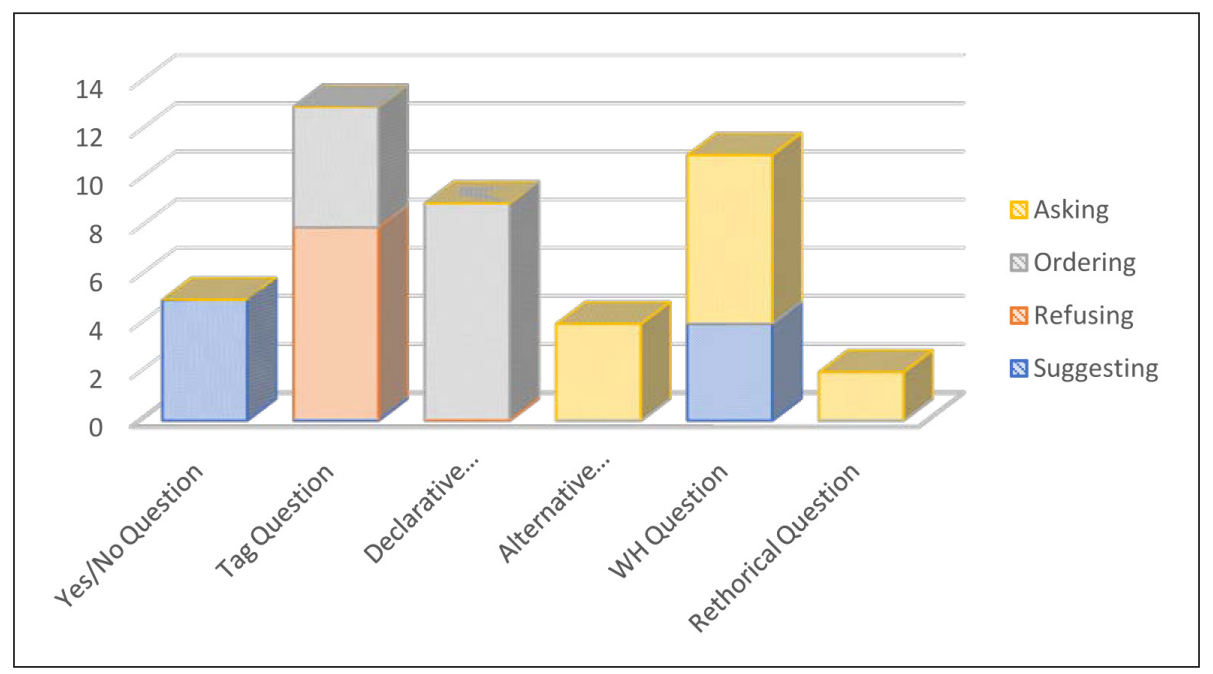

Table 1. Forms of Questions in Implications of Conversation

\section{Discussion}

The findings are grouped based on the question patterns and their functions. The explanation of each is given below.

\section{YES/NO QUESTION \\ Suggesting}

Extract 1: this conversation was between a female buyer (speaker) and a male fishmonger (interlocutor) in a fish stall. The speaker and the interlocutor were estimated to be at the same age; that was around thirty-five years. The utterance went as follows.

\begin{tabular}{ll}
\hline \multicolumn{1}{c}{ Data (Lampung Language) } & \multicolumn{1}{c}{ English Translation } \\
\hline Seller: Ngunut punyew nyow pun? (1) & Seller: What kind of fish are you looking for? \\
Buyer: Patin. Pigho satu kilew? (2) & Buyer: Catfish. How much is one kilogram of them? \\
Seller: Tigo puluh pak (3) & Seller: Thirty four \\
Buyer: Payew. Satu kilo yay (4) & Buyer: Okay, one kilo-gram, please \\
Seller: Mak lajeu wo kilo gawoh? (5) & Seller: You don't want to buy two kilos? \\
Buyer: Muwak ah. Satu kilo gawoh yay (6) & Buyer: No. just one kilo, please \\
Seller: Tunggeu sebeghai yoh (7) & Seller: Wait a minute, please \\
\hline
\end{tabular}

The question pattern of yes/no question can be found in the conversation above. The question uttered by the seller contained suggestion to the buyer to answer it with yes or no. Kareem (2014); Bianchi \& Cruschina (2015); Veloudis (2017); Sakhiyya (2017) explained that the assumption of bringing up yes/no answer by the interlocutor is the basis of the yes/no question pattern. That answer has a similar expression to the question made by the speaker as the power of a firm statement in the form of a question. The question pattern given 
in number five used a yes/no question in the negative form. Darani \& Afghari (2013); Kareem (2014) stated that a negative yes/no question is generally used to confirm in a more specific direction in the form of expectations or assumptions of the speaker.

Romero \& Chung (2004) said that the question pattern of negative yes/no question is associated with assumption that the interlocutor can grant or accept in accordance with the purpose of the speaker's question. The function of the seller's hope of utterance was to suggest; the seller recommended the buyer to buy two kilograms of fish. Frank (1990) explained that sociologically, the use of question in communication may influence the interlocutor so that the speaker gets what he wants. The fifth utterance is also a kind of negotiation utterance which indirectly asks the interlocutor in form of question.
Félix-brasdefer (2005) mentioned that indirect speech in negotiations plays an important role in communication as to arouse politeness.

\section{TAG QUESTION Refusing}

Extract 2: the following conversation happened between a female old seller (speaker) and a female interlocutor (the buyer) around the vegetable stand. The age of the speaker was assumed to be more than fifty years old, while the age of the interlocutor was assumed to be less than twenty five to thirty years old. Tempoyak is a food ingredient made of fermented durian. When uttering the forth utterance in the conversation, her facial expression changed to express sadness while opening the container and showing the quality of the tempoyak. The following was the utterance in question.

\begin{tabular}{|c|c|}
\hline Data (Javanese) & English Translation \\
\hline Buyer: Pinten tempoyak se ons, Mbah? (1) & Buyer: How much is one ounce of tempoyak, Ma'am? \\
\hline Seller: P & my dear \\
\hline Buyer: Rong on sep & inces by ten thousands, Ma'am? \\
\hline $\begin{array}{l}\text { Seller: Aduh gusti mengko Mbah ora } \\
\text { balik modal, yo kan? (4) }\end{array}$ & Seller: Dear God, then I won't get turnover, will I? \\
\hline Buyer: Yowes satu ons aja kalau gitu bu (5) & Buyer: Okay then i will buy one ounce, Ma'am. \\
\hline
\end{tabular}

\section{Ordering}

Extract 3: This conversation takes place between a male seller (fish seller) with a Batak ethnicity and a female buyer. The buyer knows the tribal background of the fish seller. If it is seen from physically, the seller and buyer have different age, the seller is around fifties and the buyer is around twenties. The conversation both of them is as follows. 


\begin{tabular}{ll}
\hline \multicolumn{1}{c}{ Data (Javanese) } & \multicolumn{1}{c}{ English Translation } \\
\hline $\begin{array}{l}\text { Buyer: Berapa ikan kembung satu } \\
\text { sekilonya opung? (1) }\end{array}$ & Buyer: How much the price one kilogram of chub \\
Seller: Empat puluh aja (2) & mackerel? \\
Buyer: Ai tiga lima aja. Sama langganan & Seller: It is only forty thousand. \\
opung (3) & Buyer: Ai, how about the thirty five thousand? I am \\
Seller: Yasudah yasudah (4) & your customer \\
Buyer: Ikannya opung yang bersihin, & Seller: Opung. Alright, alright \\
kan? (5) & Buyer: Opung will clean the chub mackerel, will \\
Seller: Ya tenang saja aku bersihkan (6) & not you? \\
\hline
\end{tabular}

In the conversation above, the question pattern of tag question (TQ) can be found in the forth utterance (see extract 2) and fifth (see extract 3). It had the purpose of re-emphasizing the opinion of the speaker delivered in the form of question. According to Roostini (2011); Tomaselli \& Gatt (2015). TQ is a subtype of question in form of understanding check, confirmation check, request for clarification by the speaker to the interlocutor. The forth utterance has the TQ pattern which is preceded by the negative form to the positive form. Kimps (2007); Tomaselli \& Gatt (2015); Sakhiyya (2017) stated that TQ Tattern is usually described first in positive form and then in negative, or vice versa. The TQ utterance in number four was ended by the particle kan. The speaker who used the particle kan assumed that the interlocutor had the same knowledge and context as she did. Hamdani \& Barnes (2018) explained that the question pattern marked by the index kan has more symmetrical knowledge between the speaker and the interlocutor.

The function of the forth utterance is to refuse (see extract 2). The meaning of this refusal is to refuse selling the speaker's product to the buyer at the price proposed by the buyer. According to Gungormezler (2016), the indirect refusal by the speaker may save the face of the speaker from any negative impressions caused by her rejection towards the positive face of the interlocutor. The seller turned down the request from the buyer by using this question.

Further, the fifth speech function, which is asking function (see extract 3). Asking isthe form actions that want the interlocutor to be able to take certain actions that can benefit to the interlocutor (Bach \& Harnish, 2000; Safar, 2016). In this data asks the interlocutor to clean up, it means the seller is asked to clean the fish that have been bought by the buyer. In addition, that utterance (extract 2 and 3) was actually one of the forms of indirect strategies to maintain politeness and to save the face of the interlocutor so that she still wanted to buy the seller's product. Pitts et al., (2014); Sukarno (2015) added that the implied utterance can be used to protect the face or selfimage of the listener through various strategies, one of which is by indirect manner or implicature. 


\section{DECLARATIVE QUESTION Ordering}

Extract 4: this conversation was between a male buyer (speaker) and an owner of a grocery store (interlocutor). The speaker was a customer and a neighbor of the interlocutor. In this conversation, after the payment was made, the speaker was seen chatting and laughing together with the interlocutor for about ten minutes. This indicated that the speaker and the interlocutor often communicated and helped each other previously. The conversation was as follows.

\begin{tabular}{ll}
\hline \multicolumn{1}{c}{ Data } & \multicolumn{1}{c}{ English Translation } \\
\hline $\begin{array}{l}\text { Buyer: Bang, gua minta beras king tiga } \\
\text { karung yang sepuluh kilogram sama } \\
\text { minyak sayur kemasan satu kilogram }\end{array}$ & $\begin{array}{l}\text { Buyer: Bro, I want three sacks of king rice, ten } \\
\text { kilograms each, and five packs of vegetable oil, one } \\
\text { kilogram each }\end{array}$ \\
$\begin{array}{ll}\text { lima (2) } \\
\text { Seller: Sapri, akuk pesanan apak ejow di } \\
\text { belakang (3) }\end{array}$ & $\begin{array}{l}\text { Seller: Sapri, please take his orders from back } \\
\text { there! }\end{array}$ \\
$\begin{array}{l}\text { Buyer: Tapi gua nggak bawa mobil pula } \\
\text { bang, mobil dibawa anak kondangan, } \\
\text { gimana ya? (4) }\end{array}$ & $\begin{array}{l}\text { Buyer: But I don't bring my car here, bro. } \text { My } \\
\text { child has taken it to a wedding reception. What to } \\
\text { deller: Ya sudah, entar pegawai gua yang }\end{array}$ \\
$\begin{array}{l}\text { deller: Okay, then, my staff will deliver them to your } \\
\text { antar ke rumah (5) }\end{array}$ & \begin{tabular}{l} 
house later \\
\hline
\end{tabular}
\end{tabular}

The question pattern in form of Declarative Question (DQ) can be found in the forth utterance. It was preceded by the speaker's statement, followed by the question with moderate intonation and then ended by the particle ' $y a$ '. According to Quirk et al., (1985), DQ has a slightly relaxed tone that does not use high intonation. Sneddon (2006) explained that the particle ' $y a$ ' can be followed by a statement and turn it into a question. In the forth utterance, the speaker provided some information and hoped that the interlocutor understood the context of the conversation so that the meaning could be revealed. Sazrubio (2018) stated that to achieve the communication goal, the speaker must intentionally convey some information to the listener, and the listener must also recognize the purpose for which the information is conveyed.
The forth speech not only gave information, but also haf an ordering function. Stivers (2010) stated that DQ can also be used more generally in conversations and for various broader functions rather than just a grammatical structure. The purpose of ordering in the conversation above was that the buyer asked the seller to deliver the purchased groceries to his house. This intention was conveyed indirectly in form of a question. According to QChłopicki (2019), it is better to use indirect speech to ask someone to do something. Urbanik \& Svennevig (2019); Prastio et al., (2019) argued that in order not to offend the interlocutor at his command, it is advisable to use the indirect speech. The forth speech also has the particle ya within its question speech. That particle can refine the function (ordering) in the buyer's speech. According to Sneddon 
(2006), particle ya or yes can act as a 'softener' in commanding speech. That speech can also show a close relationship between a seller and a buyer. Wouk (2001) explained that the discourse marker ya has an expanded function of its literal meaning, which is used to increase solidarity among conversation participants.

\section{ALTERNATIVE QUESTION Requesting}

Extract 5: The following conversation happened in a meat stall between a male seller (speaker) who is around sixty years old from Padang and a female buyer (interlocutor) who is less than twenty five years old. When engaging in this conversation, the speaker was holding his product to show the freshness of the meat which he said freshly cut. During the bargaining process, the speaker expressed his face in amazement while shaking his head. The following is the utterance between both.

\begin{tabular}{ll}
\hline \multicolumn{1}{c}{ Data } & \multicolumn{1}{c}{ English Translation } \\
\hline Buyer: Uda, ado iga sapi? (1) & Buyer: Sir, do you have beef ribs? \\
Seller: Ado dik, satu kilo lapan puluh (2) & $\begin{array}{l}\text { Seller: I do. One kilo of them is eighty thousand } \\
\text { rupiahs. }\end{array}$ \\
$\begin{array}{l}\text { Buyer: Dua kilo seratus empat puluh ya, } \\
\text { da? (3) }\end{array}$ & $\begin{array}{l}\text { Buyer: Can I have two kilos for one hundred } \\
\text { and forty rupiahs? }\end{array}$ \\
Seller: (hening) (4) & Seller: (remain silent) \\
Buyer: Da, kalau dagingnya berapa? (5) & Buyer: How much is the beef, Sir? \\
Seller: Seratus dua lima (6) & Seller: One hundred and twenty five \\
Buyer: Seratus dua lima atau seratus dua & Buyer: One hundred and twenty five or one \\
puluh, da? (7) & hundred and twenty? \\
Seller: Yaudah yaudah seratus dua puluh & Seller: Okay, take them for one hundred and \\
(8) & twenty \\
Buyer: Dua kilo, da. Tolong langsung & Buyer: Two kilos, Sir. please cut them into \\
dipotong kecil-kecil ya! (9) & small pieces! \\
\hline
\end{tabular}

In the conversation above, the Alternative Question (AQ) pattern can be found in the seventh speech. This utterance contained two choices of answers given by the speaker to the interlocutor as an alternative. Kimps (2007); Enfield et al., (2010) explained that the question pattern of AQ has two complete questions together with the word marker 'atau'(or). The purpose of this $A Q$ in a conversation was to enable the interlocutor to determine the final price of the product with the intention of narrowing down price choices. According to Channon et al., (2018), AQ pattern has the goal to narrow down the focus of the question. Besides having its own goal, the AQ pattern also has a function behind the question.

The function of the seventhutterance was to request something. The meaning of requesting in the conversation was that the buyer asked the seller to reduce the price of his product. This request was expressed in the form of a question. Wijayanto (2019) argued that 
requesting something can be expressed through a question. The above utterance was a negotiation between a buyer and a seller. Waring (2019) explained that the responses in negotiations can be expressed in the form of questions.

\section{WH-QUESTION}

Asking

Extract 6: This conversation was made by a female shallot seller (speaker) who came from Lampung and a buyer (interlocutor) along with a friend of the speaker who sold anchovy next to her. When processing the payment of the transaction, the speaker didn't have any change for the buyer since she just opened her stall. The interlocutor paid a hundred thousand bills. So the speaker asked her friend who had been selling or opening her stall from the early morning. The utterance is provided below.

\begin{tabular}{ll}
\hline \multicolumn{1}{c}{ Data (Lampung Language) } & \multicolumn{1}{c}{ English Translation } \\
\hline Seller: Ngunut nyow, Yuk? (1) & Seller: What are you looking for, Dear? \\
Buyer: Bawang merah pigho sekilo? (2) & Buyer: Shallots. How much is one kilo of them? \\
Seller: Wo waleu, Yuk. (3) & Seller: Twenty eight thousand rupiahs, Dear \\
Buyer: Payew setengah kiloyo (4) & Buyer: Okay then I'll have half a kilo of them \\
Seller: Nyow lagei, Yuk? (5) & Seller: What else, Dear? \\
Buyer: Eno gawoh. Joh (memberi uang) (6) & Buyer: (That's all. Here's the money.) \\
Seller: Adew,mak ngemik kembalianno. & Seller: (Oh no, I don't have the change. Sri, do you \\
Sri, nyow wat duit lunik? (berbicara ke & have small change? (talking to the seller next to \\
penjual sebelah) (7) & her) \\
Sri: Sebeghai, wat. Ago pigho? (8) & Sri: (Wait. I do. How much do you need?) \\
Seller: Puluh ghibeu jamo seghibeuan (9) & Seller: (Ten thousand with a thousand bills) \\
\hline
\end{tabular}

\section{Suggesting}

Extract 7: This conversation takes place between the fish seller and the buyer. The buyer is the speaker with Lampung ethnicity. It can seen from the language used, namely Lampung language. The seller, as the buyer's speech partner, switches the code to use Lampung language after the buyer uses the language. The seller and buyer are women andthey look the same age. The conversation both of them is as follows. 


\begin{tabular}{ll}
\hline \multicolumn{1}{c}{ Data (Lampung Language) } & \multicolumn{1}{c}{ English Translation } \\
\hline Seller: Nila, Gurame, Bu. (1) & Seller: tilapia, giant gourami, ma'am \\
Buyer: Nila pigho sekilow? (2) & Buyer: How much the price one kilogram of tilapia, \\
Seller: Tega puluh pak gawoh (3) & Ma'am? \\
Buyer: Ai, mak tego puluh gawoh ah (4) & Seller: It is onlythirty-four thousand \\
Seller: Mak dapok. Temen lah ijo sai & Buyer: Ai, how if the price is only thirty thousand \\
murah. Nila ranau wawai (5) & Seller: It cannot. This is really the cheapest one. \\
Buyer: Yo kidah nyak agow lemo kilo (6) & Tilapia of Ranau is good \\
Seller: Belah punggung? (7) & Buyer: Okay, I buy for five kilogram \\
Buyer: Yew (8) & Seller: Whether the back of the fish is split? \\
Seller: (memotong dan membersihkan & Buyer: Yes \\
ikan). Ijow, Bu (membungkus ikan). & Seller: (cutting and cleaning the fish). This is Ma'am \\
Ulanyow mak agow dititip ken gawoh? & (wrapping the fish) Why do not you just leave it \\
katu biyak (9) & here first? Who knows if you mind? \\
Buyer: Payew titip pai. Nyak agok bilong & Buyer: Alright, i leave it here. I want to go inside \\
dilom pai (10) & first. \\
\hline
\end{tabular}

The question pattern in form of WH-Question can be found in the seventh utterance. This utterance was in form of a question with word marker 'apa' (what), with the intention of getting information from the interlocutor. Stivers (2010); Sakhiyya (2017); Paath (2019) explained that the question pattern of $\mathrm{WH}$-Question has a characteristic in the question uttered and there is a question word like 'siapa' (who), 'apa' (what), 'di mana' (where), 'kapan' (when), 'mengapa' (why), and 'bagaimana' (how).

The utterance number seven (see extract 6) had a function to ask for something. Lindawati (2012) stated that this kind of question has a function to express a request and hope that the interlocutor will give out something needed by the speaker. The meaning of the request in the conversation above was that the seller politely asked for help from her friend so that she could exchange her money to smaller change. The speaker also maintained her good conduct in form of polite utterance by expressing her wish indirectly. According to Prastio et al., (2019); Shardimgaliev (2019), it's better to express a wish by using conversational implicature, as it will allow us to have our dignity, to be considered polite, and to be able to keep our good name in the interlocutor's view.

Next, the ninth utterance (see extract 7) has function to give suggestion. Speech of suggestion is believed to benefit the interlocutor in the future (Nugroho et al., 2018). In line with this regard, in this data, the speaker (seller) assures that the advice givenwill be very useful for the interlocutor of the speaker (buyer) if the interlocutor agrees to leave her groceries in the place of the speaker. In addition, providing solution from the seller, it describes an illustration that the seller in the market of Way at Halim-Lampung is a friendly seller and has a good personality. One of the characteristics of individual who has a good personality is caring about the circumstances (Kecskes, 2014). 


\section{Rhetorical Question: Refusing}

Extract 8: This conversation occurred between two women. The seller was a vegetable seller and aged around 35 years old, while the buyer was a Chinese young lady. It took place in a line of vegetable sellers at around 9 AM (Western Indonesian Time). The interlocutor was a customer of the speaker. From her appearance, it was likely to be that the interlocutor belonged to the upper class (considered rich). It could be seen from her clothes and the jewelry she wore while shopping. When the interlocutor bargained, the speaker slightly smiled. She was holding her six-month-old baby the whole time. The following was the utterance in question.
Data

Seller: Mau belanja sayur apa cik hari ni? (1) Buyer: Segar-segar ya kangkungnya kak (2) Seller: Ya dong cik, baru aja subuh tadi di antar (3)

Buyer: Tiga (kangkung) lima ribu kak? (4)

Seller: Ampun, dua ikat lima ribu. Apalah harga lima ribu cik (tertawa). Nggak

kasian sama gua, cik? Mana subuh gua udah di pasar bawa anak (5)

Buyer: Ya udah, ambil (6)
English Translation

Seller: What vegetables do you want to shop today?

Buyer: The water spinaches look fresh

Seller: Of course, sis, they were just delivered this dawn

Buyer: Three (bunches of them) are five thousands rupiahs?

Seller: Gosh, five thousands is for two bunches, sis (laugh). Don't you feel sorry for me, sis? I've been here in the market since dawn, bringing my child along

Buyer: All right, I'll take them.
In the conversation above, the fifth utterance is a question pattern in form of Rhetorical Question (RQ). That utterance didn't need an answer for the question asked to the interlocutor. It was rather expressed to reprimand the interlocutor not to buy the product in the price proposed by her. Heinemann (2008); Heinemann (2010) explained that $\mathrm{RQ}$ is a question designed not to receive answers from the interlocutor, but rather to challenge or reprimand the interlocutor. This utterance is also a rhetorical utterance that is persuasive and is used to persuade the interlocutor to buy the product sold by the speaker. Rhetorical question is a persuasive technique used by the speaker through the speaker's character and emotion so that the interlocutor will act as expected by the speaker (Frank, 1990; Supardi, 2016). The rhetoric in form of a question in the utterance number five aimed to persuade or change the perception of the buyer so that she wanted to follow the seller's will, that is, to buy two bundles of water spinach for five thousands rupiahs. Platonova (2016) stated that the performance of rhetorical functions related to the creative use of language is formed by the speakers who focus on influencing the interlocutors in order to change their perceptions about certain things, such as making them act, think, behave, speak, and even feel in certain ways.

RQ is an important aspect in interaction and communication process that has communicative effect. According to (Niamh et al., 2014), the 
rhetoric is now seen as an important part of socialinteraction and communication which is more than an ornamental utterance. Besides, that utterance in the conversation above has a function to refuse. The meaning of this refusal was that the seller refused to sell her products to the buyer in the bargained price. That refusal was expressed indirectly in form of a question. Refusing indirectly by using RQ will not damage the speaker's relationship with the customer, and the use of her conversational implicature is considered polite. It is risky if the speaker refuses directly. Gungormezler (2016) stated that the failure to use the method of rejecting appropriately to the interlocutor can have social consequences for the speaker, e.g., risking interpersonal relationships with the interlocutor.

\section{CONCLUSION}

Questions in the conversational implicature of transactions in traditional markets that occur between sellers and buyers (the speakers) have the expectation of continuation or action from theinterlocutorsinaccordance with the wishes of the speaker. Compared to buyers, sellers more often use questions with a variety of patterns that contain other functions than to get information, i.e. to ask and to reject. This is because sellers need polite utterance in order to make the transaction happen. Thus, they use conversational implicatures in form of questions. The sellers and buyers in Way Halim Market are of multilingual societies (Lampung, Java, and Padang). All three communities often use conversational implicature in the form of questions. The addition of the particle kan and ya in the questions, followed by certain intonation and emphasis, has double function that is to create communicative effect.

This research was expected to provide a reference in transactions and polite communication processes in everyday life. Using questions that contained conversational implicature in the process of transactions made the sellers or the buyers have the dignity so that they got good feedback from their interlocutors. This research was also expected to be good resource for subsequent researches regarding utterances that occur in transactions.

\section{ACKNOWLEDGEMENTS}

The authors would to thank warmly to the lecturers State University of Malang and the reviewers for their comments and useful suggestions.

\section{REFERENCES}

Aliyah, I., Setioko, B., \& Pradoto, W. (2017). City , Culture and Society Spatial $\mathrm{fl}$ Exibility in Cultural Mapping of Traditional Market Area in Surakarta ( A Case Study of Pasar Gede in Surakarta ). City, Culture and Society, 36, 1-11. https:// doi.org/10.1016/j.ccs.2017.05.004

Bach, K., \& Harnish, M. R. (2000). Linguistic Communication and Speech Acts. New York: The MIT Press.

Bezhanishvili, G., Löbner, S., Richter, V., \& Frank, M. (2011). Logic, Language, and Computation (Issue September). London New York: Springer Heidelberg Dordrecht.

Bezuidenhout, A. L., \& Morris, R. K. (2004). Implicature, Relevance and Default Pragmatic Inference. Experimental 
Pragmatics, 257-282. https://doi. org/10.1057/9780230524125_12

Bianchi, V., \& Cruschina, S. (2015). The Derivation and Interpretation of Polar Questions with a Fronted Focus. Lingua, 1-22. https://doi. org/10.1016/j.lingua.2015.10.010

Channon, A., Foulkes, P., \& Walker, T. (2018). But What Is the Reason Why You Know Such Things? : Question and Response Patterns in the LADO Interview. Journal of Pragmatics, 129, 154-172. https://doi. org/10.1016/j.pragma.2018.03.015

Darani, L. H., \& Afghari, A. (2013). Variability in English Yes/ No Questions: A Study of Communicative Functions. Procedia - Social and Behavioral Sciences, 70, 1664-1670. https://doi. org/10.1016/j.sbspro.2013.01.238

Enfield, N. J., Stivers, T., \& Levinson, S. C. (2010). Question-Response Sequences in Conversation Across Ten Languages: An introduction. Journal of Pragmatics, 42(10), 26152619. https://doi.org/10.1016/j. pragma.2010.04.001

Félix-brasdefer, J. C. (2005). Indirectness and Politeness in Mexican Requests. Selected Proceedings of the 7th Hispanic Linguistics Symposium, García 1993, 66-78.

Frank, J. (1990). You Call that a Rhetorical Question? Journal of Pragmatics, 14(5), 723-738. https://doi.org/10.1016/03782166(90)90003-V

Gawne, L. (2016). Questions and Answers in Lamjung Yolmo. Journal of Pragmatics, 101, 3153. https://doi.org/10.1016/j. pragma.2016.04.002
George, E. J., \& Mamidi, R. (2020). Conversational implicatures in English Dialogue: Annotated Dataset. Procedia Computer Science, 171(2019), 2316-2323. https://doi. org/10.1016/j.procs.2020.04.251

Grice, H. P. (1975). Logic and Conversation. Syntax and Semantics, 3(2), 41-58.

Gungormezler,T.(2016). AnInvestigation of The Refusal Speech Act Of Turkish Learners Of English. Kansas State University.

Hafrianto, J., \& Mulyadi. (2018). Kalimat Tanya dalam Bahasa Melayu Dialek Tamiang. LITERA: Jurnal Penelitian Bahasa, Sastra, Dan Pengajarannya, 17-2(Juli), 186-201.

Hamdani, F., \& Barnes, S. (2018). Polar Questions in Colloquial Indonesian: A pilot Study. Journal of Pragmatics, 132, 1-20. https://doi. org/10.1016/j.pragma.2018.05.002

Heinemann, T. (2008). Questions of Accountability: Yes-No Interrogatives That Are Unanswerable. IDscourse Studies, 10(1), 55-71.

Heinemann, T. (2010). The QuestionResponse System of Danish. Journal of Pragmatics, 42, 27032725. https://doi.org/10.1016/j. pragma.2010.04.007

Kareem, R. (2014). A Pragmatic Analysis of Yes / No Questions in English with Reference to Press Conferences. Procedia - Social and Behavioral Sciences, 136, 3640. https://doi.org/10.1016/j. sbspro.2014.05.283

Kecskes, I. (2014). Politeness and Impoliteness. In Intercultural Pragmatics, $\quad 8(2)$. https://doi. 
org/10.1093/acprof:oso/97801998 92655.003 .0010

Kimps, D. (2007). Declarative Constant Polarity Tag Questions: A DataDriven Analysis of Their Form , Meaning and Attitudinal Uses. Journal of Pragmatics, 39, 270 291. https://doi.org/10.1016/j. pragma.2006.08.003

Koentjaraningrat. (2016). Pengantar Ilmu Antropologi. Jakarta: Rineka Cipta.

Lee, E. L. (2019). Language and Culture Language and Culture (Issue November). Oxford University Press. https://doi.org/10.1093/ acrefore/9780190228613.013.26

Levinson, S. C. (2010). ^ Dnye , the Papuan Language of Rossel Questions and Responses in Y é 11 Island. Journal of Pragmatics, 42(10), 2741-2755. https://doi. org/10.1016/j.pragma.2010.04.009

Lindawati. (2012). Fungsi Tutur Kalimat Tanya Bahasa Indonesia. LITERA: Jurnal Penelitian Bahasa, Sastra, Dan Pengajarannya, 11(2), 2012.

Niamh, B., Merkl-Davies, \& M, D. (2014). Rhetoric and Argument in Social and Environmental Reporting : the Dirty Laundry Case. Accounting, Auditing \& Accountability Journal, 27(4), 602-633. https://doi. org/10.1108/AAAJ-04-2013-1333

Nugroho, M., Tarjana, S. S., \& Purnanto, D. (2018). The Speech Acts of Suggestion by Islamic Preachers (Da'i) in Dialogic Da'wah in the City of Surakarta. 4th PRASASTI International Conference on Recent Linguistics Research (PRASASTI 2018), 166(Prasasti), 401-405. https://doi.org/10.2991/prasasti18.2018 .73

Paath, R. (2019). Questioning System in Manado Malay (A Study of Syntactic). 2nd International Conference on Social Science (ICSS 2019), 383(Icss), 844-848. https:// doi.org/10.2991/icss-19.2019.48

Paul, O., Farid, M., Hisyam, M., \& Said, I. (2018). The Cultural Sustainability of Traditional Market Place in Africa: A New Research Agenda. Journal of Rural Studies, 62(July), 87-106. https://doi.org/10.1016/j. jrurstud.2018.07.001

Pitts, M. J., Fowler, C., Fisher, C. L., Smith, S. A., Fisher, C. L., \& Smith, S. A. (2014). Politeness Strategies in Imagined Conversation Openers About Eldercare. Journal of Language and Social Psychology, 33(1), 29-48. https://doi. org/10.1177/0261927X13506708

Platonova, M. (2016). Applying Emotive Rhetorical Strategy to Environmental Communication in English and Latvian. Procedia - Social and Behavioral Sciences, 236(December 2015), 107-113. https://doi.org/10.1016/j. sbspro.2016.12.044

Prastio, B., Ibrahim, A. S., \& Susanto, G. (2019). Conversation Implicature in Interrogative Utterance of The Discourse of E-Commerce Business Advertisement. Jurnal Pendidikan: Teori, Penelitian, Dan Pengembangan, 4(7), 906-911.

Prastio, B., Ibrahim, A. S., Susanto, G., \& Nurzafira, I. (2020). Yes/ No Question On Conversation Implicature in Advertising E-Commerce. Journal of Intensive Studies on Language, 
Literature, Art, and Culture, 4(1), 1-7. https://doi.org/10.1017/ CBO9781107415324.004

QCh $\square$ opicki, W. (2019). Declarative Questions in Polish Student Conversations. Journal of Pragmatics, xxxx, 1-11. https://doi. org/10.1016/j.pragma.2019.03.003

Quirk, Randolph, Greenbaum, Sidney, Leech, Geoffrey, Svartvik, J. (1985). A Comprehensive Grammar of the English Language. Longman.

Ratu, D. M., Meruntu, O. S., \& Palar, W. R. (2018). Pragmatic Implicature of ManadoMalay Speakers' Questions. 1st International Conference on Social Sciences (ICSS 2018), 226(Icss), 908912. https://doi.org/10.2991/icss18.2018 .188

Romero, Maribel and Chung, $\mathrm{H}$. H. (2004). On Negative Yes/No Question. Linguistics and Philosophy, 27(5), 609-658.

Roostini, K. E. (2011). A reflection on Teacher Questioning Types. Indonesian Journal of Applied Linguistics, 1(1), 10-24. https://doi. org/10.17509/ijal.v1i1.96

Safar, M. (2016). Tindak Tutur Direktif dalam Transaksi Jual Beli di Pasar Sentral Watampone. Humanus, XV(2), 167-176. http://ejournal. unp.ac.id/index.php/humanus/ index

Sakhiyya, Z. (2013). Question Formation of Bahasa Indonesia as a Second Language. Indonesian Journal of Applied Linguistics, 3(1), 138-147. https://doi.org/doi.org/10.17509/ ijal.v3i1.196

Sakhiyya, Z. (2017). Negotiating Social Identity Through Questions in Casual Conversations: A Critical Discourse Analysis. Indonesian
Journal of Applied Linguistics, 6(2), 311-318. https://doi.org/doi. org/10.17509/ijal.v6i2.4916

Salmon, W. (2011). Conventional Implicature, Presupposition, and the Meaning of must. Journal of Pragmatics, 43(14), 3416-3430. https://doi.org/10.1016/j. pragma.2011.07.011

Saz-rubio, M. M. Del. (2018). Female Identities in TV Toiletries Ads : A Pragmatic and Multimodal Analysis of Implied Meanings. Journal of Pragmatics, 136, 54-78. https://doi. org/10.1016/j.pragma.2018.07.009

Shardimgaliev, M. (2019). Implicatures in Judicial Opinions. International Journal for the Semiotics of Law, 32(2), 391-415. https://doi.org/10.1007/ s11196-018-09601-4

Sneddon, J. . (2006). Colloquial Jakartan Indonesian. Pacific Linguistics, Research School of Pacific and Asian Studies, Australian National University.

Stivers, T. (2010). An Overview of the Question-Response System in American English Conversation. Journal of Pragmatics, 42(10), 27722781. https://doi.org/10.1016/j. pragma.2010.04.011

Sukarno. (2015). Politeness Strategies in Responding to Compliments in Javanese. Indonesian Journal of Applied Linguistics, 4(2), 91-101. https://doi.org/10.17509/ijal. v4i2.686

Supardi. (2016). Language Power In Courtroom: The Use Of Persuasive Features In Opening Statement. Indonesian Journal of Applied Linguistics, 6(1), 70-78. https://doi. org/10.17509/ijal.v6i1.2663 
Tomaselli, M. V., \& Gatt, A. (2015). Italian Tag Questions and their Conversational Functions. Journal of Pragmatics, 84, 54-82. https://doi. org/10.1016/j.pragma.2015.05.001

Urbanik, P., \& Svennevig, J. (2019). Managing Contingencies in Requests: the Role of Negation in Norwegian Interrogative Directives. Journal of Pragmatics, 139, 109125. https://doi.org/10.1016/j. pragma.2018.10.014

Vallejo, D. R. (2017). Actuality Effects As Conversational Implicatures. Journal of Pragmatics, 112, 4467. https://doi.org/10.1016/j. pragma.2017.02.005

Veloudis, I. (2017). Exploiting Polar Questions for Expressive Purposes : " Queclaratives "' and "“ Whimperatives "' in Modern Greek. Lingua, 1-17. https://doi. org/10.1016/j.lingua.2017.12.008
Waring, H. Z. (2019). Problematizing Information-Seeking WHQuestions. Language an Communication, 64, 81-90. https://doi.org/10.1016/j. langcom.2018.11.001

Wijayanto, P. W. (2019). A Contrastive Analysis of Imperative Sentences in English and Javanese Language. Social Sciences \& Humanities, 27(September), 2047-2053.

Wouk, F. (2001). Solidarity in Indonesian conversation: The Discourse Marker Ya. Journal of Pragmatics, 33(99), 171-191. https://doi.org/10.1016/S03782166(99)00139-3 